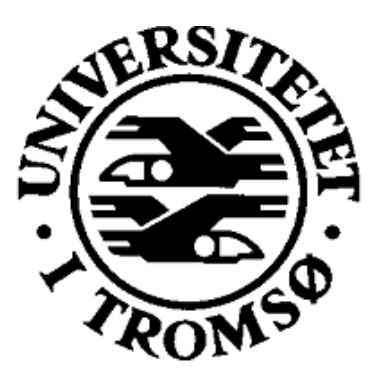

\title{
High-Sensitivity C-Reactive Protein Is an Independent Risk Factor for Non-Vertebral Fractures in Women and Men: the Tromsø Study
}

\author{
MED-3950 5.-årsoppgaven
}

Profesjonsstudiet i medisin ved UiT Norges Arktiske Universitetet

Kristoffer Dahl, med.stud

Mk-09

Veiledere:

Hovedveileder Åshild Bjørnerem, Dr med, forsker og spesialist i fødselshjelp og gynekologi

Biveileder Luai Awad Ahmed, Dr med og forsker

Institutt for Helse og Omsorgsfag, UiT Norges Arktiske Universitet

UiT Norges Arktiske Universitet

April 2014

Troms $\emptyset$ 


\section{Preface}

The work went largely in accordance with the plan that I had set up. I spent the first part of the time (spring 2013) to read up on the subject and articles that dealt with the work I was going to write about. During the spring I began to write this report. After graduating in 2013 and the following summer I started getting results and could, in cooperation with my supervisor and co-supervisor, Åshild Bjørnerem and Luai Ahmed respectively, begin to interpret them. I spent the rest of the summer and autumn of 2013 to complete the report. During this process I was under the close supervision of my supervisor who showed me how to interpret the results in a critical way.

The only deviation from the original plan was that I used data from Troms $\varnothing 5$ instead of Troms $\varnothing 4$ as the data from the Troms $\varnothing 5$ was more complete for my purposes.

I want to extend my gratitude to my supervisor Luah Ahmed for doing the statistical work, the Troms $\varnothing$ Study for providing data and especially I want to thank my supervisor Åshild Bjørnerem for the tremendous amount of help and support she has given me. 


\section{Content list}

Introduction ............................................................................................................. 1

Materials and Methods ....................................................................................... 2

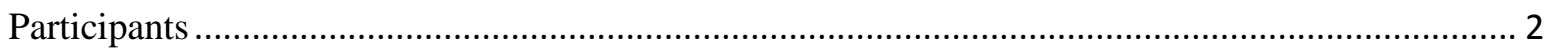

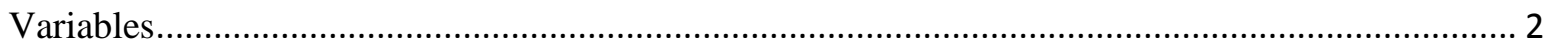

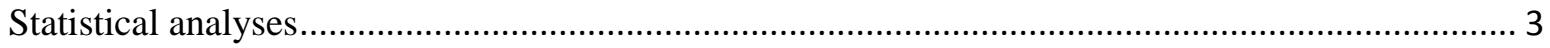

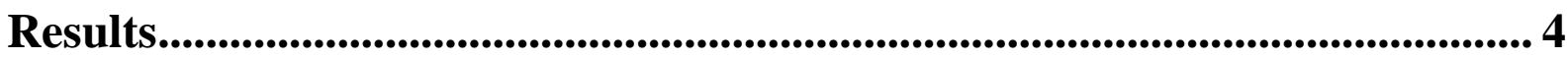

Characteristics and fracture rates in women and men ................................................................. 4

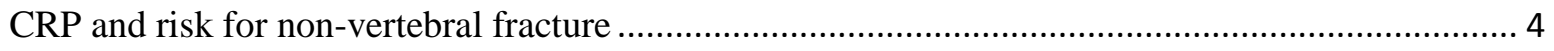

CRP and BMD

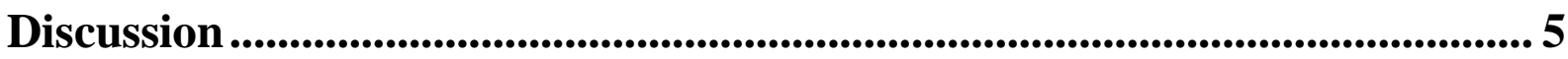

Tables and Figure ...................................................................................................... 11 


\begin{abstract}
Background:

Low grade inflammation is associated with fractures, while the relationship between inflammation and bone mineral density (BMD) is less clear. Moreover, eventual gender differences in the sensitivity to inflammation are still poorly elucidated. We therefore tested the hypothesis that high-sensitivity $\mathrm{C}$-reactive protein (CRP) is an independent risk factor for non-vertebral fractures, and that CRP is associated with BMD, in both genders.
\end{abstract}

\title{
Method:
}

We included 1902 women and 1648 men aged 55 and 74 years, who had CRP measured at baseline in the Troms $\varnothing$ Study, Norway in 2001. All non-vertebral fractures were registered from X-ray archives at the University Hospital of North Norway during an average of 7.2 years follow-up. Cox's proportional hazard models were used for fracture prediction by CRP and linear regression analyses for its association with BMD, and adjusted for other risk factors.

\section{Results:}

During 25595 person-years, 366 (19\%) women and $126(8 \%)$ men suffered nonvertebral fractures. Each standard deviation (SD) increase in log CRP increased the risk for non-vertebral fracture by $13 \%$ in women and $22 \%$ in men (hazard ratios (HRs) 1.13; $95 \%$ confidence interval $(\mathrm{CI}) 1.03-1.26, p=0.026$ and $1.22 ; 95 \%$ CI $1.00-1.48, p=$ 0.046, respectively). Those with CRP in the upper tertile, exhibited a $39 \%$ and $80 \%$ higher risk for fracture than those in the lowest tertile in women and men, respectively (HRs 1.39; 95\% CI 1.06-1.83, $p=0.017$ and $1.8095 \%$ CI 1.10-2.94, $p=0.019$ ). Higher levels of CRP were associated with lower BMD in men, not in women.

\section{Conclusion:}

CRP is an independent risk factor for non-vertebral fractures in both genders. As the association between CRP and BMD showed conflicting results, we infer that inflammation may influence fracture risk differently in women than men via factors beyond what is explained by the association between CRP and BMD. 


\section{Introduction}

Bone fragility is a public health problem due to the accompanying increased morbidity, mortality, and financial costs resulting from fractures, in particular, non-vertebral and hip fractures. ${ }^{(1,2)}$ In women and men aged 50 years, the remaining lifetime risk for fragility fractures is $46 \%$ and $22 \%$, respectively. ${ }^{(3)}$ To reduce the burden of fragility fracture, a better understanding of the pathogenesis and mechanisms that influence on bone loss and result in fracture is needed.

Chronic inflammation is associated with a range of diseases such as rheumatoid arthritis and other autoimmune diseases, ${ }^{(4)}$ cardiovascular diseases ${ }^{(5,6)}$ and diabetes mellitus. ${ }^{(7)}$ There is an increasing body of evidence indicating that chronic diseases are associated with fragility fractures and that chronic inflammation is associated with fragility fractures even in the absence of disease. ${ }^{(8-10)}$ Systemic diseases, such as rheumatoid arthritis, inflammatory bowel disease and systemic lupus erythematosus are associated with bone loss..$^{(4,8,9)}$ Each factor that contributes to bone loss expresses its effect through the final common pathway of bone modeling and remodeling, and bone loss is caused by the negative balance between bone formation and bone resorption within each of the bone multicellular units (BMU). ${ }^{(1)}$ It has been established through in vitro experiments and rodent studies that inflammation plays a vital part in this remodeling process that is contributing to an increased bone resorption and in some cases inhibiting bone formation. ${ }^{(12-15)}$

In studies of low grade inflammation, higher levels of high-sensitivity C-reactive protein (CRP) are associated with an increased risk of fracture. ${ }^{(10,16-23)}$ Some studies were relatively small, ${ }^{(10,20)}$ while one huge study of more than 18000 participants included only hospitalized fracture cases. ${ }^{(18)}$ None of these previous studies have reported an effect of CRP on risk for fracture in women and in men in gender-stratified analyses. However, the association between levels of CRP and bone mineral density (BMD) is conflicting. ${ }^{(16,21,24,25)} \mathrm{A}$ recent study showed that CRP was not associated with femoral neck and lumbar spine BMD, but inversely associated with bone strength index, which partially explained the increased fracture risk that was associated with inflammation. ${ }^{(17)}$ We hypothesized that higher levels of CRP increase the risk of nonvertebral fracture in Troms $\varnothing$, a population with a high incidence of fracture, and we aimed to test whether CRP is an independent risk factor for non-vertebral fractures, and whether CRP is associated with BMD, in both genders. 


\section{Materials and Methods}

\section{Participants}

The Troms $\varnothing$ Study is a population-based, prospective study of various health issues and chronic diseases, and is a resource for the surveillance of disease risk factors. It consists of six surveys referred to as Troms $\varnothing 1-6$, which have been conducted in Troms $\varnothing$ from 1974 to $2008 .{ }^{(26)}$ At the fifth survey (Tromsø 5) in 2001-2002 a total of 10353 women and men aged 32-74 years were invited and 8130 (79\%) participated. For this current study, we selected those 4225 participants (2581 women and 1707 men) aged 55 and 74 years who had a valid CRP measurement at baseline in Troms $\varnothing 5$ and no pathological fracture during follow-up. We excluded 675 subjects on medical treatment (corticosteroids $(n=75)$, bisphosphonates for osteoporosis $(n=207)$, aromatase inhibitors for breast cancer $(n=13)$ and hormone replacement therapy $(n=380)$. This left 3550 participants included in the analyses (1902 women and 1648 men). The Troms $\varnothing$ Study was approved by the Data Inspectorate of Norway and the Regional Committee of Medical and Health Research Ethics, North Norway. All participants gave written informed consent.

\section{Variables}

At baseline, two self-administered questionnaires were filled in, which included information on self-perceived health, chronic diseases, such as diabetes, cardiovascular diseases, asthma and cancer, and current use of medications, calcium and vitamin D supplementation, current smoking and level of physical activity. A physical activity score was made by adding the hours/week of moderate and hard leisure time physical activity, giving the hours with hard activity double weight: score $=$ moderate +2 hard. Participants were also asked to write a list of brand names of medicines used on a regular basis. The questionnaire information was checked by health personnel at the study site. The data collection is described in detail elsewhere. ${ }^{(26)}$ An English translation of the questionnaires is available at the Tromsø Study homepage. ${ }^{(27)}$

Baseline height and weight were measured in light clothing without shoes, and body mass index (BMI) was calculated as weight divided by the square of height $\left(\mathrm{kg} / \mathrm{m}^{2}\right)$. BMD was measured at the total hip and femoral neck by Dual-energy X-ray 
Absorptiometry (DXA, GE Lunar Prodigy; Lunar Corporation, Madison, WI, USA). ${ }^{(28)}$ The coefficients of variation $(\mathrm{CV})$ were $1.2 \%$ and $1.7 \%$ for the total hip and femoral neck, respectively; details of the measurement methods, the strict quality control procedures for densitometry, and long-term performance of the densitometers are described previously. ${ }^{(28)}$ CRP was measured by a particle-enhanced immunoturbidimetric assay from Roche Diagnostics, with a detection limit of $0.12 \mathrm{mg} / \mathrm{l}$ and the CV was $1.4 \%$. Blood samples were analyzed at the Department of Clinical Chemistry, University Hospital of North Norway, Troms $\varnothing$.

All non-vertebral fractures were registered from the X-ray archives of the University Hospital of North Norway in Troms $\varnothing$, between their participations in Troms $\varnothing$ 5 in 2001-2002 and January $12010 .^{(29,30)}$ All fractures are registered here, because this is the only X-ray service in the city or within $250 \mathrm{~km}$. The only exception would be fractures occurring while traveling with no control X-ray after returning home. The validation of the fracture registration has previously been reported. ${ }^{(31)}$ Follow-up time was assigned from baseline to the first fracture, death, migration, or to the end of follow-up January 1 2010. In this study we included the first fracture, which we defined as any non-vertebral fracture (except finger, toes, and face and skull). Vertebral fractures are not included in this register.

Statistical analyses

Naturally log-transformation corrected for skewed distribution of CRP. Analysis of variance (ANOVA) was used to compare groups, and linear regression analyses for $\mathrm{p}$ for trend. Cox's proportional hazards regression models were used to estimate hazard ratios (HRs) (the ratio between the chance of a certain outcome in a population and the same outcome in a control population) for fracture with $95 \%$ confidence interval (CI). The proportionality assumptions of the models were verified. The HRs were adjusted for age, BMI, height, current smoking, physical activity, self-reported history of a chronic disease (diabetes, cardiovascular diseases, asthma and cancer) and use of medications and supplementation (insulin, statins, painkiller, calcium and vitamin D) known to be associated with fracture risk. ${ }^{(32,33)}$ Linear regression analyses were used for testing of the association between BMD and CRP. In order to perform direct comparison, we present standardized regression coefficients, which are standard deviation (SD) change in BMD per SD change in log CRP. The SAS Software package, v9.2 (SAS Institute 
Inc., Cary, NC, USA) and STATA 12.0 (StataCorp, College Station, TX, USA) were used for statistical analyses.

\section{Results}

Characteristics and fracture rates in women and men

In women and men, the mean baseline age was 64.8 years (SD 5.3) and 65.8 years (SD 4.9), median CRP was $1.48 \mathrm{mg} / \mathrm{L}$ (range 0.17-86.4) and $1.63 \mathrm{mg} / \mathrm{L}$ (range 0.22-116.9), respectively. Women and men with higher levels of CRP had higher BMI, larger proportion of chronic diseases, and lower levels of physical activity, while men, not women with high CRP, were older, (all $p$ for trend $<0,001$, Table 1). The fracture rates in the lowest, middle and upper tertiles of CRP were 27.2 (95\% CI 22.8-32.4), 24.8 (20.6-29.8) and 29.3 (24.7$34.8), p$ for trend $=0.592$ in women, and 8.6 (6.2-11.9), 8.9 (6.4-12.3) and 14.1 (10.818.4), $p$ for trend $=0,039$ in men, respectively.

CRP and risk for non-vertebral fracture

During 25595 person-years and an average of 7.2 years follow-up, 366 (19\%) of 1902 women and $126(8 \%)$ of 1648 men suffered at least one incident non-vertebral fracture. In women, each SD higher levels of log CRP increased the risk for non-vertebral fracture by $11 \%$ after adjustment for age and total hip BMD (HR 1.11; 95\% CI 1.00-1.23, $p=0.053$, Table 2). After further adjustment for height, BMI, previous fracture and self-reported chronic diseases the fracture risk increased by $13 \%$ (HR 1.13; 95\% CI 1.02-1.26, $p=$ 0.026). In men, each SD higher levels of log CRP increased the risk for non-vertebral fracture by $25 \%$ after adjustment for age and total hip BMD (HR 1.25; 95\% CI 1.04-1.50, $p=0.018$, Table 2). After further adjustment for height, BMI, previous fracture, selfreported and chronic diseases, the fracture risk increased by $22 \%$ (HR 1.22; 95\% CI 1.00$1.48, p=0.046)$. Those with CRP in the upper tertile exhibited $39 \%$ higher risk for fracture than those in the lowest tertile of CRP in women (HR 1.39, 95\% Cl 1.06-1.83, $p=0.017$ ), and $80 \%$ higher risk for fracture in men (HR $1.8095 \% \mathrm{Cl} 1.10-2.94, p=0.019$, Table 3) after accounting for BMD and other risk factors. Additional adjustment for use of medication, physical therapy and smoking made no substantial change in the result in both genders. 


\section{CRP and BMD}

In women, each SD higher levels of $\log \mathrm{CRP}$ was associated with $0.16 \mathrm{SD}$ and $0.12 \mathrm{SD}$ higher BMD at the total hip and femoral neck after age adjustment and before $(p<0.001)$, but not after adjustment for BMI ( $p=0.281$ and $p=0.387$, respectively, Table 4). In men, $\log$ CRP was not associated with BMD in age adjusted models $(p=0.609$ and $p=0.259$, respectively), however, after adjustment for BMI each SD higher levels of log CRP was associated with $0.08 \mathrm{SD}$ and $0.09 \mathrm{SD}$ lower BMD at the total hip and femoral neck ( $p=$ 0.001). Additional adjustment for comorbidity and other covariates made no substantial change in the result in both genders.

\section{Discussion}

We report that higher levels of CRP are associated with non-vertebral fractures after accounting for BMD in women and men in gender-stratified analyses. In men, not in women, increasing CRP was associated with BMD. Thus, our results are confirming previous reports of a relationship between CRP and fracture risk, and also confirming the conflicting results for association between CRP and BMD.

The European Prospective Investigation into Cancer Norfolk reported an U shaped association between CRP levels and risk of fracture with the lowest risk in the intermediate range, and increased risk of fracture observed in the lower end and upper levels of CRP. ${ }^{(18)}$ That huge study included 18586 women and men of which 792 suffered fractures during a median follow-up of about 15 years. However, only hospitalized fractures were registered, as they did not screen the whole population. They reported U-shaped associations in both genders, albeit the associations were nonsignificant. ${ }^{(18)}$ In our current study, there was a similar but non-significant U-shaped association.

Nakamura et al. reported an increased risk for vertebral and hip fracture in 751 elderly Japanese women above 69 years of age by higher levels of CRP. ${ }^{(16)}$ Rolland et al. reported that men with the highest levels of CRP had higher odds for prevalent fracture than men with lower levels of CRP, but CRP levels were not associated with BMD at any site. ${ }^{(21)}$ An interesting finding in that study was that higher CRP levels were associated with lower trabecular BMD, lower trabecular number and larger trabecular separation at the distal radius. However, the association between CRP and fracture remained unchanged after accounting for the trabecular microarchitecture. ${ }^{(21)}$ 
Among 906 women and men between 40 and 79 years of age in the Bruneck study, higher levels of CRP were associated with a higher risk for fracture independent of BMD, bone turnover markers and chronic diseases. ${ }^{(10)}$ Pasco et al. reported in their prospective study on 444 white women above 65 years an increased risk for fracture by increasing CRP, with minimal changes in results after accounting for bone turnover, lifestyle factors, medication and comorbidity. ${ }^{(20)}$ In addition, they reported no association between CRP and BMD in those women. ${ }^{(20)}$ Cauley et al. showed in their prospective study of 2681 women and men during 5.8 years a marginal association between CRP and fracture risk after adjusting for multiple variables. ${ }^{(19)}$ They further reported the highest risk for fracture in subjects who had high levels of three or more inflammation markers in comparison with subjects with no elevated markers. ${ }^{(19)}$

Eriksson et al. reported in a prospective study of 2910 elderly men that higher levels of CRP increased the risk for fracture, and these fractures were mainly vertebral, and the effect of CRP was independent of BMD and other risk factors. ${ }^{(23)}$ In that study CRP was not significant associated with hip fracture or non-vertebral fragility fracture. Similarly, Oei et al. reported that CRP was most strongly associated with fracture of the spine, also significantly associated with hip fracture, but not with wrist fractures in a cohort of 6386 women and man with 1561 fractures in the Rotterdam Study. ${ }^{(22)}$ CRP was not significantly associated with BMD in both studies. ${ }^{(22,23)}$

In cross-sectional and prospective studies, higher CRP is reported associated with a lower BMD and increased bone loss at both hip and spine. ${ }^{(24,25)}$ Other studies showed that BMD did not decrease by higher CRP levels. ${ }^{(16,21)}$ and two of them even reported a lower BMD with a lower CRP. ${ }^{(16,17)}$ In addition, prospective studies have reported no association between CRP and BMD in those women. ${ }^{(10,19,20,22,23)}$ In the current study, higher CRP was associated with lower BMD in men not in women, in line with the previous conflicting results. An interesting finding was that after adjustment for BMI, a positive association between $\mathrm{CRP}$ and $\mathrm{BMD}$ changed to a non-significant negative association in women, which is similar as reported by ishii et al. ${ }^{(17)}$ In contrast, this association changed from non-significant to a significant inverse association in men, in the current study. These changes were not explained by interaction between CRP and BMI and may need further investigation.

The uncertainties pertaining to associations between CRP and BMD suggest that CRP may modulate fractures risks through mechanisms other than by producing bone loss. One recent interesting study by Ishii et al. showed that compressive strength and 
bending strength indices at the femoral neck were inversely associated with CRP. ${ }^{(17)}$ The calculation of these strength estimates were based on bone size and body size and proportions, known to be important for bone strength independent of BMD. ${ }^{(17)}$ After accounting for these strength indices, the association between CRP and fracture risk was attenuated, and could partially explain the increased risk of fracture related to inflammation. ${ }^{(17)}$ Another mechanism was suggested by Ding et al. who reported that a higher IL-6 was associated with a lower BMD after adjusted for other inflammatory markers such as TNF-a and CRP. ${ }^{(25)} \mathrm{Kim}$ et al. observed that higher CRP levels were associated with increased BTM (bone turnover rates) using bone specific alkaline phosphatase, suggesting that reduced BMD values may be associated with subclinical inflammation. ${ }^{(34)}$ In contrast, Schett et al. reported higher BTM by increasing CRP, ${ }^{(10)}$ while Rolland et al reported no association between BTM and CRP. ${ }^{(21)}$ In addition, local rather than circulating inflammation markers may regulate bone remodeling via autocrine or paracrine mechanisms. ${ }^{(25)}$

Our large population based study, which was based on a validated fracture registry, has several limitations. We did not include vertebral fractures in the registry. Cytokines and bone remodeling markers were not available, so we could not study whether the association between fracture risk and CRP was mediated via these factors as reported by others. ${ }^{(19,35)}$ Finally we did not have statistical power to study the association between CRP and different types of fracture.

In summary this study adds to the growing evidence that chronic inflammation increase fracture risk in both genders. The association between CRP and BMD, however remains less clear and the divergent results in the two genders recorded in this study suggests that other mechanisms unrelated to bone mass may be involved and need to be further explored. 


\section{References}

1. Cummings SR, Melton LJ. Epidemiology and outcomes of osteoporotic fractures. Lancet. 2002;359(9319):1761-7.

2. Kanis JA, Oden A, Johnell O, De Laet C, Jonsson B, Oglesby AK. The components of excess mortality after hip fracture. Bone. 2003;32(5):468-73.

3. Kanis JA, Johnell O, Oden A, et al. Long-term risk of osteoporotic fracture in Malmö Osteoporos Int. 2000;11(8):669-74.

4. Gough AK, Lilley J, Eyre S, Holder RL, Emery P. Generalised bone loss in patients with early rheumatoid arthritis. Lancet. 1994;344(8914):23-7.

5. Danesh J, Wheeler JG, Hirschfield GM, et al. C-reactive protein and other circulating markers of inflammation in the prediction of coronary heart disease. N Engl J Med. 2004;350(14):1387-97.

6. Kaptoge S, Di AE, Lowe G, et al. C-reactive protein concentration and risk of coronary heart disease, stroke, and mortality: an individual participant meta-analysis. Lancet. 2010;375(9709):132-40.

7. Dehghan A, van Hoek M, Sijbrands EJ, Stijnen T, Hofman A, Witteman JC. Risk of type 2 diabetes attributable to C-reactive protein and other risk factors. Diabetes Care. 2007;30(10):2695-9.

8. Jahnsen J, Falch JA, Mowinckel P, Aadland E. Bone mineral density in patients with inflammatory bowel disease: a population-based prospective two-year follow-up study. Scand J Gastroenterol. 2004;39(2):145-53.

9. Spector TD, Hall GM, McCloskey EV, Kanis JA. Risk of vertebral fracture in women with rheumatoid arthritis. BMJ. 1993;306(6877):558.

10. Schett G, Kiechl S, Weger S, et al. High-sensitivity C-reactive protein and risk of nontraumatic fractures in the Bruneck study. Arch Intern Med. 2006;166(22):2495501.

11. Parfitt AM, Mathews CH, Villanueva AR, Kleerekoper M, Frame B, Rao DS. Relationships between surface, volume, and thickness of iliac trabecular bone in aging and in osteoporosis. Implications for the microanatomic and cellular mechanisms of bone loss. J Clin Invest. 1983;72(4):1396-409.

12. Clowes JA, Riggs BL, Khosla S. The role of the immune system in the pathophysiology of osteoporosis. Immuno Rev. 2005;208:207-27.

13. Lacativa PG, Farias ML. Osteoporosis and inflammation. Arq Bras Endocrinol 
Metabol. 2010;54(2):123-32.

14. Bertolini DR, Nedwin GE, Bringman TS, Smith DD, Mundy GR. Stimulation of bone resorption and inhibition of bone formation in vitro by human tumour necrosis factors. Nature. 1986;319(6053):516-8.

15. König A, Mühlbauer RC, Fleisch H. Tumor necrosis factor alpha and interleukin-1 stimulate bone resorption in vivo as measured by urinary $[3 \mathrm{H}]$ tetracycline excretion from prelabeled mice. J Bone Miner Res. 1988;3(6):621-7.

16. Nakamura K, Saito T, Kobayashi R, et al. C-reactive protein predicts incident fracture in community-dwelling elderly Japanese women: the Muramatsu study. Osteoporos Int. 2011;22(7):2145-50.

17. Ishii S, Cauley JA, Greendale GA, et al. C-reactive protein, bone strength, and nineyear fracture risk: data from the Study of Women's Health Across the Nation (SWAN). J Bone Miner Res. 2013;28(7):1688-98.

18. Ahmadi-Abhari S, Luben RN, Wareham NJ, Khaw KT. C-reactive protein and fracture risk: European Prospective Investigation into Cancer Norfolk Study. Bone. 2013;56(1):67-72.

19. Cauley JA, Danielson ME, Boudreau RM, et al. Inflammatory markers and incident fracture risk in older men and women: the Health Aging and Body Composition Study. J Bone Miner Res. 2007;22(7):1088-95.

20. Pasco JA, Kotowicz MA, Henry MJ, et al. High-sensitivity C-reactive protein and fracture risk in elderly women. JAMA. 2006;296(11):1353-5.

21. Rolland T, Boutroy S, Vilayphiou N, Blaizot S, Chapurlat R, Szulc P. Poor trabecular microarchitecture at the distal radius in older men with increased concentration of high-sensitivity C-reactive protein--the STRAMBO study. Calcif Tissue Int. 2012;90(6):496-506.

22. Oei L, Campos-Obando N, Dehghan A, et al. Dissecting the relationship between high-sensitivity serum C-reactive protein and increased fracture risk: the Rotterdam Study. Osteoporos Int. 2014;25(4):1247-54.

23. Eriksson AL, Moverare-Skrtic S, Ljunggren Ö, Karlsson M, Mellström D, Ohlsson C. High-sensitivity CRP is an independent risk factor for all fractures and vertebral fractures in elderly men: the MrOS Sweden study. J Bone Miner Res. 2014;29(2):41823.

24. Koh JM, Khang YH, Jung CH, et al. Higher circulating hsCRP levels are associated with lower bone mineral density in healthy pre- and postmenopausal women: evidence 
for a link between systemic inflammation and osteoporosis. Osteoporos Int. 2005;16(10):1263-71.

25. Ding C, Parameswaran V, Udayan R, Burgess J, Jones G. Circulating levels of inflammatory markers predict change in bone mineral density and resorption in older adults: a longitudinal study. J Clin Endocrinol Metab. 2008;93(5):1952-8.

26. Jacobsen BK, Eggen AE, Mathiesen EB, Wilsgaard T, Njølstad I. Cohort profile: the Tromsø Study. Int.J.Epidemiol. 2012;41(4):961-7.

27. The Troms $\varnothing$ study [internet]. 2014 [cited 2010 Apr 14]. Available from: http://www.tromsostudy.com

28. Emaus N, Omsland TK, Ahmed LA, Grimnes G, Sneve M, Berntsen GK. Bone mineral density at the hip in Norwegian women and men--prevalence of osteoporosis depends on chosen references: the Troms $\varnothing$ Study. Eur.J.Epidemiol. 2009;24(6):321-8.

29. Ahmed LA, Center JR, Bjørnerem A, et al. Progressively increasing fracture risk with advancing age after initial incident fragility fracture: the Troms $\emptyset$ study. J Bone Miner Res. 2013;28(10):2214-21.

30. Bjørnerem A, Ahmed LA, Jørgensen L, Størmer J, Joakimsen RM. Breastfeeding protects against hip fracture in postmenopausal women: the Troms $\emptyset$ study. J Bone Miner Res. 2011;26(12):2843-50.

31. Joakimsen RM, Fønnebø V, Søgaard AJ, Tollan A, Størmer J, Magnus JH. The Troms study: registration of fractures, how good are self-reports, a computerized radiographic register and a discharge register? Osteoporos.Int. 2001;12(12):1001-5.

32. Joakimsen RM, Fønnebo V, Magnus JH, Størmer J, Tollan A, Søgaard AJ. The Troms Study: physical activity and the incidence of fractures in a middle-aged population. $\mathbf{J}$ Bone Miner Res. 1998;13(7):1149-57.

33. Joakimsen RM, Fønnebø V, Magnus JH, Tollan A, Søgaard AJ. The Troms $\varnothing$ Study: body height, body mass index and fractures. Osteoporos.Int. 1998;8(5):436-42.

34. Kim BJ, Yu YM, Kim EN, Chung YE, Koh JM, Kim GS. Relationship between serum hsCRP concentration and biochemical bone turnover markers in healthy pre- and postmenopausal women. Clin.Endocrinol.(Oxf). 2007;67(1):152-8.

35. Barbour KE, Boudreau R, Danielson ME, et al. Inflammatory markers and the risk of hip fracture: the Women's Health Initiative. J Bone Miner Res. 2012;27(5):1167-76. 
Tables and Figure

Table 1. Baseline characteristics and non-vertebral fracture rate $(95 \% \mathrm{CI})$ by CRP tertiles: The Troms $\varnothing$ Study.

\begin{tabular}{|c|c|c|c|c|}
\hline & \multicolumn{3}{|c|}{ CRP tertiles } & \multirow[t]{2}{*}{$\boldsymbol{P}$} \\
\hline Women & $n=640$ & $n=630$ & $n=632$ & \\
\hline CRP (mg/L), range & $0.17-0.98$ & $0.99-2.37$ & $2.39-86.4$ & \\
\hline $\mathrm{CRP}(\mathrm{mg} / \mathrm{L})$ & $0.61 \pm 0.22$ & $1.56 \pm 0.40$ & $7.10 \pm 9.41$ & $<0.001$ \\
\hline Age (years) & $64.5 \pm 5.2$ & $64.8 \pm 5.3$ & $65.1 \pm 5.3$ & 0.061 \\
\hline $\mathrm{BMI}\left(\mathrm{kg} / \mathrm{m}^{2}\right)$ & $25.0 \pm 3.5$ & $27.7 \pm 4.3$ & $29.3 \pm 5.3$ & $<0.001$ \\
\hline Height $(\mathrm{cm})$ & $161.8 \pm 6.0$ & $161.6 \pm 6.0$ & $161.2 \pm 6.0$ & 0.222 \\
\hline Weight (kg) & $65.1 \pm 9.7$ & $72.0 \pm 12.3$ & $75.8 \pm 14.1$ & $<0.001$ \\
\hline Total hip BMD $\left(\mathrm{g} / \mathrm{cm}^{2}\right)^{*}$ & $0.87 \pm 0.12$ & $0.90 \pm 0.13$ & $0.92 \pm 0.14$ & $<0.001$ \\
\hline Femoral neck BMD $\left(\mathrm{g} / \mathrm{cm}^{2}\right)^{*}$ & $0.81 \pm 0.11$ & $0.84 \pm 0.11$ & $0.85 \pm 0.12$ & $<0.001$ \\
\hline Physical activity score & $3.7 \pm 2.3$ & $3.3 \pm 2.1$ & $3.2 \pm 2.2$ & $<0.001$ \\
\hline Current smoking, n (\%) & $158(24.7)$ & $142(22.5)$ & $183(29.0)$ & 0.082 \\
\hline Poor self-perceived health, n (\%) & $246(39.3)$ & $247(39.7)$ & $298(48.4)$ & 0.001 \\
\hline Self-reported chronic disease, $\mathrm{n}(\%)$ & $133(20.8)$ & $153(24.3)$ & $182(28.8)$ & 0.001 \\
\hline \multicolumn{5}{|l|}{ Medications/supplements } \\
\hline Insulin, $\mathrm{n}(\%)$ & $3(0.5)$ & $7(1.1)$ & $12(1.9)$ & 0.021 \\
\hline Painkillers, n (\%) & $118(18.4)$ & $117(18.6)$ & $163(25.8)$ & 0.001 \\
\hline Statins, n $(\%)$ & $85(13.3)$ & $76(12.1)$ & $66(10.4)$ & 0.119 \\
\hline Calcium and/or vitamin $\mathrm{D}, \mathrm{n}(\%)$ & $183(28.6)$ & $195(31.0)$ & $177(28.0)$ & 0.821 \\
\hline Incident of fracture, $\mathrm{n}(\%)$ & $124(19.4)$ & $112(17.8)$ & $130(20.6)$ & 0.592 \\
\hline Fracture rate/1000 person year $(95 \% \mathrm{CI})$ & $27.2(23-32)$ & $24.8(21-30)$ & $29.3(25-35)$ & \\
\hline Men & $\mathrm{n}=553$ & $\mathrm{n}=546$ & $\mathrm{n}=549$ & \\
\hline CRP (mg/L), range & $0.22-1.07$ & $1.08-2.39$ & $2.4-116.9$ & \\
\hline $\mathrm{CRP}(\mathrm{mg} / \mathrm{L})$ & $0.68 \pm 0.23$ & $1.66 \pm 0.38$ & $7.32 \pm 9.70$ & $<0.001$ \\
\hline Log-CRP mean $\pm \mathrm{SD}$ & $-0.45 \pm 0.38$ & $0.48 \pm 0.23$ & $1.65 \pm 0.71$ & $<0.001$ \\
\hline Age (years) & $65.2 \pm 4.9$ & $66.2 \pm 4.8$ & $66.1 \pm 5.1$ & 0.001 \\
\hline Body mass index $\left(\mathrm{kg} / \mathrm{m}^{2}\right)$ & $26.2 \pm 3.3$ & $27.2 \pm 3.5$ & $27.7 \pm 3.5$ & $<0.001$ \\
\hline Height (cm) & $175.1 \pm 6.7$ & $174.7 \pm 6.6$ & $174.4 \pm 6.4$ & 0.164 \\
\hline Weight (kg) & $80.2 \pm 12.0$ & $82.7 \pm 12.5$ & $84.0 \pm 12.2$ & $<0.001$ \\
\hline Total hip BMD $\left(\mathrm{g} / \mathrm{cm}^{2}\right)^{*}$ & $1.03 \pm 0.14$ & $1.01 \pm 0.14$ & $1.02 \pm 0.14$ & 0.215 \\
\hline Femoral neck BMD $\left(\mathrm{g} / \mathrm{cm}^{2}\right)^{*}$ & $0.94 \pm 0.13$ & $0.92 \pm 0.13$ & $0.93 \pm 0.13$ & 0.043 \\
\hline Physical activity score & $4.5 \pm 2.4$ & $4.0 \pm 2.4$ & $3.8 \pm 2.5$ & $<0.001$ \\
\hline Current smoking, $\mathrm{n}(\%)$ & $103(18.6)$ & $143(26.2)$ & $200(36.4)$ & $<0.001$ \\
\hline Poor self-perceived health, n (\%) & $168(30.6)$ & $194(36.1)$ & $224(41.6)$ & $<0.001$ \\
\hline Self-reported chronic disease, n (\%) & $156(28.2)$ & $190(34.8)$ & $210(38.3)$ & $<0.001$ \\
\hline \multicolumn{5}{|l|}{ Medications/supplements } \\
\hline Insulin, $\mathrm{n}(\%)$ & $6(1.1)$ & $8(1.5)$ & $13(2.4)$ & 0.098 \\
\hline Painkillers, n (\%) & $47(8.5)$ & $50(9.2)$ & $65(11.8)$ & 0.063 \\
\hline Statins, n (\%) & $100(18.1)$ & $89(16.3)$ & $90(16.4)$ & 0.454 \\
\hline Calcium/vitamin D, n (\%) & $96(17.4)$ & $98(18.0)$ & $88(16.0)$ & 0.559 \\
\hline Incident of fracture, $\mathrm{n}(\%)$ & $36(6.5)$ & $36(6.7)$ & $54(9.8)$ & 0.039 \\
\hline Fracture rate/1000 person-year $(95 \% \mathrm{CI})$ & $8.6(6.2-12)$ & $8.9(6.4-12)$ & $14.1(11-18)$ & \\
\hline
\end{tabular}


Table 2: Hazard ratio (HR) $(95 \% \mathrm{CI})$ for non-vertebral fracture per 1 standard deviation higher levels of log high sensitivity C-reactive protein in women and men: The Troms $\varnothing$ Study

\begin{tabular}{lcccccccc}
\hline & \multicolumn{4}{c}{ Women } & \multicolumn{4}{c}{ Men } \\
\cline { 2 - 9 } & $\mathrm{N}$ & $\mathrm{Fx}$ & $\mathrm{HR}(95 \% \mathrm{CI})$ & $p$ value & $\mathrm{N}$ & $\mathrm{Fx}$ & HR $(95 \% \mathrm{CI})$ & $p$ value \\
\hline Model 1 & 1902 & 366 & $1.03(0.93-1.14)$ & 0.573 & 1648 & 126 & $1.18(1.00-1.39)$ & 0.056 \\
Model 2 & 1698 & 331 & $1.11(1.00-1.23)$ & 0.053 & 1410 & 102 & $1.25(1.04-1.50)$ & 0.018 \\
Model 3 & 1690 & 330 & $1.13(1.02-1.26)$ & 0.026 & 1405 & 102 & $1.22(1.00-1.48)$ & 0.046 \\
\hline
\end{tabular}

Model 1 adjusted for age.

Model 2 adjusted for age, total hip bone mineral density (BMD).

Model 3 adjusted for age, total hip BMD, body mass index (BMI), height, previous fracture, and selfreported diseases (myocardial infarction, angina pectoris, asthma, diabetes mellitus, cancer).

$\mathrm{N}=$ number of subjects in the model, $\mathrm{Fx}=$ number of subjects with fracture, $\mathrm{CI}=$ confidence interval

Table 3: Hazard ratios (HRs) (95\% CI) for non-vertebral fracture by tertiles of high sensitivity C-reactive protein (CRP) in women and men: The Troms $\varnothing$ Study.

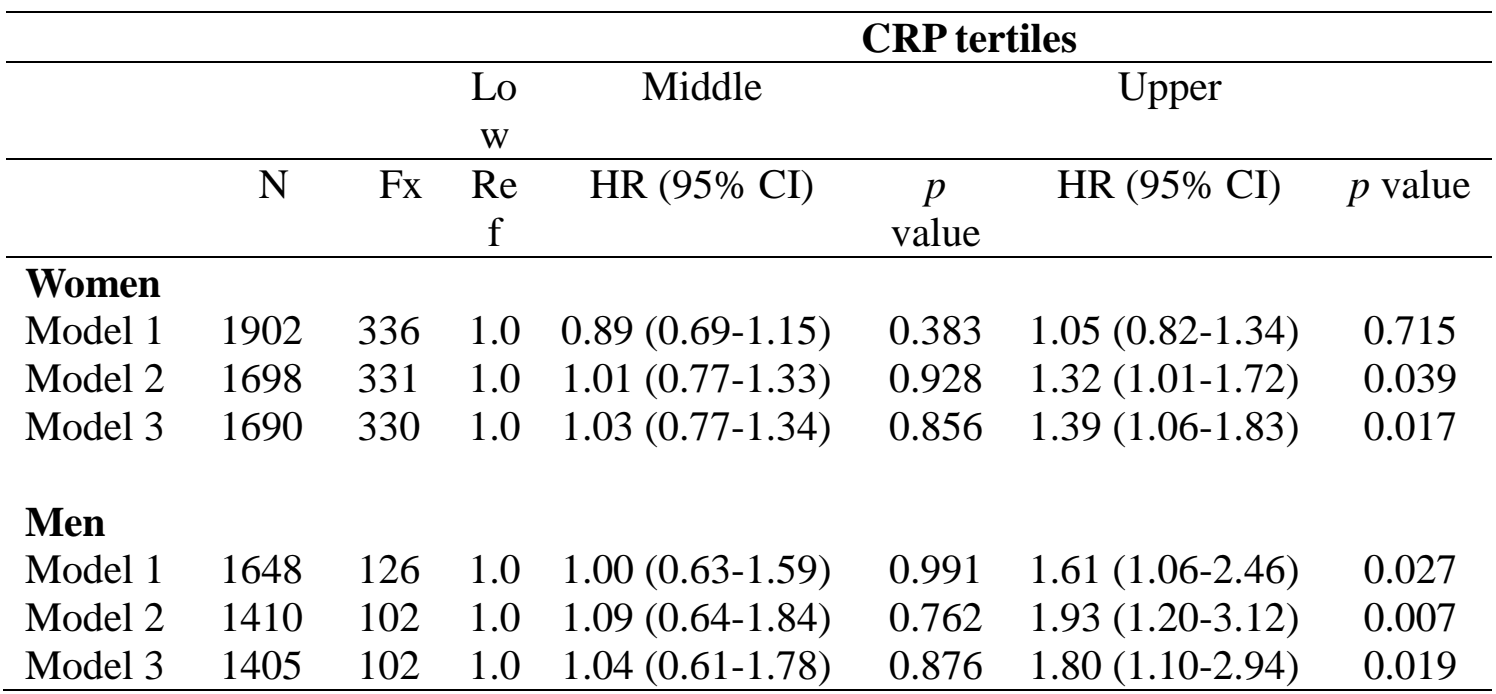

Model 1 adjusted for age.

Model 2 adjusted for age, total hip bone mineral density (BMD).

Model 3 adjusted for age, total hip BMD, body mass index (BMI), height, previous fracture, and selfreported diseases (myocardial infarction, angina pectoris, asthma, diabetes mellitus, cancer).

$\mathrm{N}=$ number of subjects in the model, $\mathrm{Fx}=$ number of subjects with fracture, $\mathrm{CI}=$ confidence interval 
Table 4: Association between bone mineral density (BMD) at the total hip and femoral neck with high sensitivity C-reactive protein (CRP) in women and men: The Troms $\emptyset$ Study

\begin{tabular}{lcrcr}
\hline & Total hip BMD $\left(\mathbf{g} / \mathbf{c m}^{2}\right)$ & \multicolumn{2}{c}{ Femoral neck BMD $\left(\mathbf{g} / \mathbf{c m}^{2}\right)$} \\
\hline Women & STB $(95 \%$ CI $)$ & $p$ value & STB $(95 \%$ CI $)$ & $p$ value \\
Model 1 & $0.164(0.118,0.211)$ & $<0.001$ & $0.121(0.075,0.167)$ & $<0.001$ \\
Model 2 & $-0.024(-0.068,0.020)$ & 0.281 & $-0.021(-0.067,0.026)$ & 0.387 \\
Model 3 & $-0.021(-0.064,0.022)$ & 0.348 & $-0.017(-0.062,0.028)$ & 0.447 \\
& & & & \\
Men & & & & \\
Model 1 & $-0.014(-0.066,0.039)$ & 0.609 & $-0.030(-0.081,0.022)$ & 0.259 \\
Model 2 & $-0.083(-0.133 ;-0.033)$ & 0.001 & $-0.085(-0.136,-0.035)$ & 0.001 \\
Model 3 & $-0.079(-0.128,-0.029)$ & 0.002 & $-0.078(-0.128,-0.029)$ & 0.002 \\
\hline Model 1
\end{tabular}

Model 1 adjusted for age.

Model 2 adjusted for age and body mass index (BMI).

Model 3 adjusted for age, BMI, height, history of previous fracture, and self-reported diseases (myocardial infarction, angina pectoris, asthma, diabetes mellitus, cancer).

$\mathrm{STB}=$ standardized coefficient, $\mathrm{CI}=$ confidence interval

Fig. 1: HR (hazard ratios) with 95\% confidence interval (95\% CI) for non-vertebral fracture by tertiles of high sensitivity C-reactive protein (hsCRP), as shown in model 4 in Table 3.
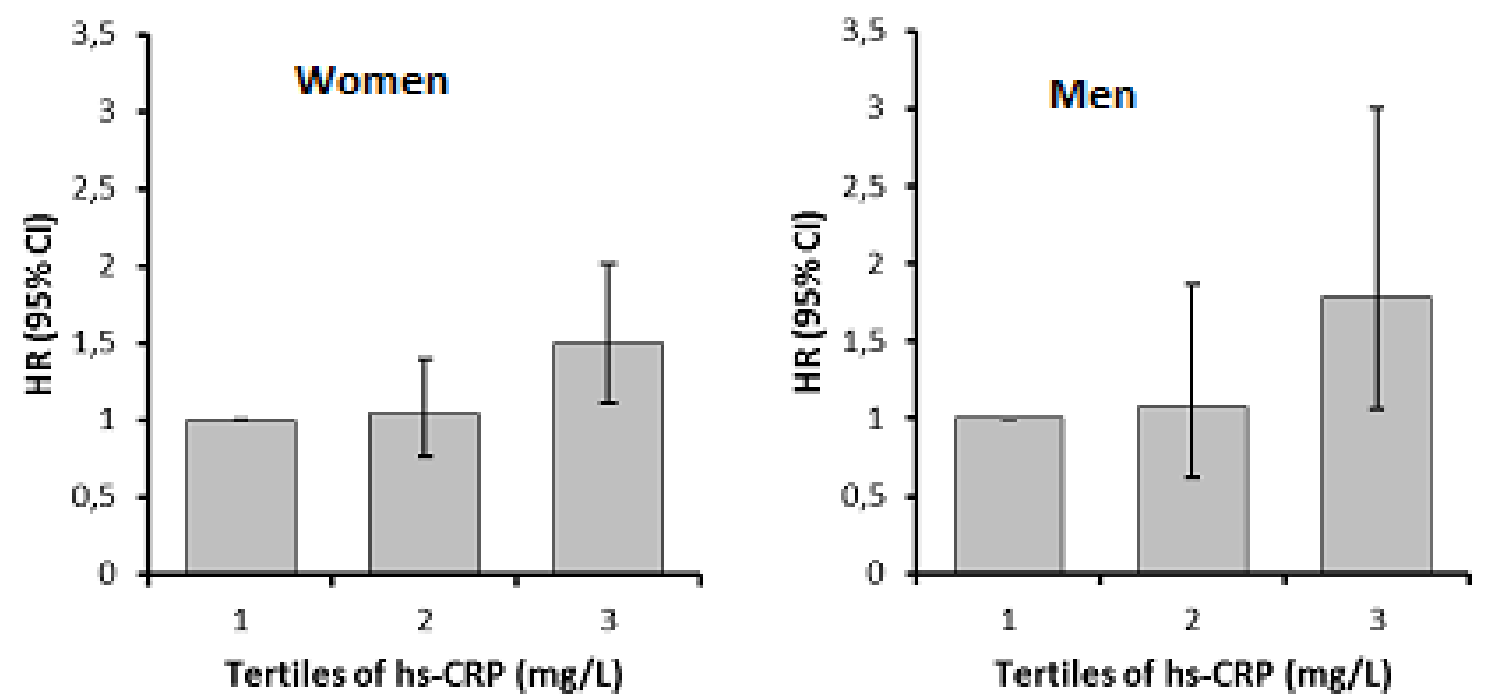